\title{
Impact of foliar application with seaweed extract, amino acids and vitamins on yield and berry quality of some Grapevine cultivar
}

\author{
El-Sese, A.M., A.K.A. Mohamed, Eman A.A. Abou-Zaid and A.M.M. Abd-El-Ghany* \\ Department of Pomology, Faculty of Agriculture, Assiut University, 71526 Assiut, Egypt
}

\begin{abstract}
Experiments were conducted during four consecutive seasons of 2017, 2018, 2019 and 2020 on three grape cultivars including "Bez-El-Anza", "Thompson Seedless" and "Red Roomy" planted at the Experimental Orchard of fruit section, Faculty of Agriculture, Assiut University in a complete randomized blocked design. This investigation was carried out to study the effect of spraying Seaweed extract, Amino acids and Vitamins on C/N ratio, yield and berry quality of some grape cultivars. The obtained results showed that Tyrosin at 500 ppm recorded the highest yield $(9.47 \mathrm{~kg} / \mathrm{vine})$ during the $1^{\text {st }}$ season. All treatments had a significant impact in the respect of TSS \%, acidity\% and TSS/acid ratio. Concerning C/N ratio, Vit.B12 at $150 \mathrm{ppm}$ recorded the highest ratio (44.85) during the $1^{\text {st }}$ season. Hence, the present study concluded applications of Seaweed extract, amino acid and Vitamins improved vine $\mathrm{C} / \mathrm{N}$ ratio, yield and berry attributes of "Bez-El-Anza", 'Thompson Seedless' and "Red Roomy" grape cultivars.
\end{abstract}

Keywords: Amino acid, Berry quality, C/N ratio, Seaweed extract, Vitamins, Yield

\section{Introduction}

Grapevine (Vitis vinifera L.) is the major fruit crop in the world not only for fresh consumption, but also raisins and wine industry. Most of grape cultivars grown in Egypt belong to the table grapes and all of them are European cultivars. Most of these cultivars are newly imported cultivars and have been planted in new reclaimed areas; however, old soils in the Middle and Upper Egypt are still planted on a large scale with "Red Roomy" and "Thompson Seedless' cultivars. For "Red Roomy", berry looseness is a severe issue, while the prevalent issue in 'Thompson Seedless' is cluster compactness. "Bez-El-Anza" is one of the local grape cultivars grown in Egypt especially in some of the old Delta farms. "Bez-El-Anza"

\footnotetext{
*Corresponding author: Ahmad Abd El-Ghany

Ahmed.Abd_Elgany@agr.au.edu.eg

Received: April 8, 2020;

Accepted: April 23, 2020;

Published: May 1, 2020.
}

cultivar is favored among local varieties due to its quality attributes such as cluster compactness berry is oval and long, yellowish green at maturity, seeded with sweet taste and firm texture. It has the advantage of midseason ripening time in mid-July. However, this cultivar characterized by low bud fertility, accordingly lower yield is expected. According to the Ministry of Agriculture Statistics 2017, the total area dedicated for grapes attained 197293 feddans including 186157 feddans as fruitful vines producing about 1734424 tons with an average of 9.317 tons/feddan. Foliar applications of seaweed extract have been recorded to affect the development, productivity and quality of some grape cultivars, including “'Thompson Seedless'” (Abada, 2014). Spraying grapevines with sea weed or amino acid extracts generally improves yield and fruit quality of grapevines cultivars and other fruits (Gad El- 
Kareem and Abd El- Rahman, 2013, Mohamed et al., 2013, Mohamed, 2014 and Carvalho et $a l ., 2019)$ as well as on other fruit trees (ElSharony etal., 2015; Ahmed, 2016).

The positive impacts of amino acids and vitamins on the development, yield and quality of grapevine cultivars have been highlighted by the results of (Ahmed et al., 2011; Madian and Refaai, 2011; Khan et al. 2012; El-Sayed, 2013; Abd-Elaal et al. 2014; Al-Khawaga, 2014; Ahmed et al., 2014; Al-Wasfy, 2014; Ahmed et al. 2015). Previous studies showed that using amino acids (Ahmed et al., 2012; Abdelaal, 2012; Abdelaal et al., 2013; Al-Khawaga, 2014; Mohamed, 2014; Abdel aziz et al., 2017; Mohamed, 2017) were very effective in advancing grapes quality in different grape cvs. The use of vitamins is followed by improving Alpha-ketoglutaric acid biosynthesis, which is combined with ammonia to form amino acids and proteins, regulating the incidence of illnesses and stimulating biosynthesis of natural hormones such as IAA, Cytokines and Gibberellins, cell division, plant pigments, enzymes, organic foods and plant metabolism.

This study aimed to shed more light on the influence of spraying some algae extracts, amino acids and vitamins on vine nutritional status and berry quality of "Bez-El-Anza", "Thompson Seedless" and "“Red Roomy"” grape cultivars grown under Assiut climatic conditions.

\section{Materials and Methods}

\section{Vineyard site and plant material:}

Experiments were conducted during four consecutive seasons of 2017, 2018, 2019 and 2020 on three grape cultivars including "Bez-El-
Anza", 'Thompson Seedless' and "Red Roomy" planted at the experimental orchard of fruit section, Faculty of Agriculture, Assiut University.

"Bez-El-Anza”, 'Thompson Seedless' and "Red Roomy" cultivars were 16,9 and 12 years old at the beginning of the experiment, respectively and were planted at $2 \times 2.5 \mathrm{~m}$ apart for 'Thompson Seedless' and "Red Roomy" and $3 \times 2.5$ m apart for "Bez-El-Anza" cultivar. Fifty standardized grapevines from each cultivar were selected in a split plot design. "Red Roomy" and 'Thompson Seedless' cultivars were pruned as a traditional head training system with 18 fruiting spurs and 3 buds on each spur for "Red Roomy" and 5 buds for 'Thompson Seedless' and 5 replacement spurs, where "Bez-El-Anza" cultivar was pruned as a classical cane training system with 6 fruit canes and 6-8 buds on each cane and 7-8 renewal spurs. Thus, the total buds left on each vine were 54 buds for "Red Roomy", 90 buds for 'Thompson Seedless' and 36-48 buds for "Bez-El-Anza" cultivar.

\section{Treatments}

1. Spraying with Seaweed extract at $2 \mathrm{~g} / \mathrm{l}$ : (Nitrogen $0.5 \%$ - Organic matter 50\% Potassium 16\% - Phosphorous 1\% Alginic acid 16\% - Cytokinin and gibberelin 600 ppm (minimum) - Mannitol $1: 6 \%$ - Water solubility $100 \%$ - Amino acids 2\% - PH 8:11) from Agrofarm ( company.

2. Spraying with amino acid (mix.) at 500 ppm.

3. Spraying with Glycin at $500 \mathrm{ppm}$.

4. Spraying with Methionin at $500 \mathrm{ppm}$.

5. Spraying with Lysin at $500 \mathrm{ppm}$.

6. Spraying with Tyrosin at $500 \mathrm{ppm}$.

7. Spraying with Folic acid at $150 \mathrm{ppm}$.

8. Spraying with Vit. B6 at $150 \mathrm{ppm}$.

9. Spraying with Vit. B12 at $150 \mathrm{ppm}$.

10. Control (water only). 
Vines were sprayed using a Knapsack sprayer (2 L). A total volume of 10 lit was sufficient for spraying 5 vines at maximum vine growth. A surfactant "Rexy film" at $0.5 \mathrm{ml} / \mathrm{L}$. was added to the spraying solutions. Both, amino acids and vitamins were used in free form whereas algae extract was "Seaweed compound". The spraying compounds were added three times: at $10 \mathrm{~cm}$ length of the new shoots, full bloom and a month after full bloom. Each treatment consisted of 5 vines (replicates) and horticultural practices such as irrigation, soil management and fertilization have been implemented as recommended. The following measurements were taken on each vine:

1- Yield (kg)/vine.

2- Total soluble solids (TSS \%), total acidity (T.A) (expressed as \% tartaric acid) and TSS/acid ratio was then calculated.

3- Total carbohydrates $\%$, Total Nitrogen $\%$ were determined in one-year old wood and then $\mathrm{C} / \mathrm{N}$ ratio was calculated.

\section{Statistical analysis:}

Experiment was setup as a randomized complete blocked design (RCBD)(10x3) with five replications for each treatment and one vine per each. The treatments were put in the subplot and the cultivars in the whole plots. The analysis of variance (ANOVA) was applied using Proc Mixed of SAS package version 9.2 (SAS, 2008) and means were compared by using the revised L.S.D. test at 5\% level of the probability (Steel and Torrie, 1981).

\section{Results}

\section{Yield (kg)/ vine:}

Table (1) showed that during the three seasons of study, all tested treatments significantly surpassed the control respecting yield/vine with no significant differences between them. The most effective treatment in this respect was Tyrosin at $500 \mathrm{ppm}$ which recorded (9.47 $\mathrm{kg} / \mathrm{vine}$ ) during the $1 \mathrm{st}$ season. Amino acid mixture Lysin and Vit.B12 also recorded higher values in this respect.

During the $2^{\text {nd }}$ season, the same table suggested that amino acid mixture, Glycin, Lysin and Tyrosin demonstrated the highest values. Glycin and folic acid, followed by Vit.B12 which recorded the highest values during the $3^{\text {rd }}$ season. On the other side, significant differences could be observed between the studied cultivars during the three seasons. "Red Roomy" surpassed the other two cultivars during the three seasons.

The interaction effect showed that Tyrosin during the $1^{\text {st }}$ and $2^{\text {nd }}$ seasons on "Red Roomy" recorded the highest values followed by Glycin during $3^{\text {rd }}$ season for the same cultivar.

\section{Total soluble solids (TSS\%):}

Table (2) showed during the three seasons of study, all tested treatments significantly surpassed the control respecting total soluble solids with no significant differences between them. The most effective treatment in this respect was Seaweed extract during the $1^{\text {st }}$ season (19.33\%). Amino acid mixture and Methionin also recorded higher values in this respect.

During the $2^{\text {nd }}$ season, the same table suggested that Glycin and Lysin demonstrated the highest values. Amino acid mixture and Vit.B6 recorded the highest values during the $3^{\text {rd }}$ season.

On the other side, significant differences could be observed between the studied cultivars during the three seasons. "Thompson Seedless" surpassed the other two cultivars during the three seasons.

The interaction effect demonstrated that amino acid mixture, Tyrosin and Vit.B6 on " Thompson Seedless" cultivar recorded the highest values during the 1 st season compared the other two seasons. 


\section{Total acidity (\%):}

Table (3) showed during the three seasons of study, all tested treatments significantly decreased compared to the control respecting total acidity. The most effective treatment in this respect was Lysin during the $1^{\text {st }}$ season $(0.34$ $\%)$. Methionin and Tyrosin also recorded lower values in this respect with no significant differences between them. During the $2^{\text {nd }}$ season, the same table suggested that Methionin and Tyrosin demonstrated the least values. Methionin and Vit.B12 recorded the least values during the $3^{\text {rd }}$ season. On the other side, significant differences could be observed between the studied cultivars during three seasons. "Red Roomy" gave the least values during the three seasons, while "“"Bez-ElAnza"" gave the least value during the $1^{\text {st }}$ season.

The interaction effect demonstrated that Methionin, Lysin and Tyrosin on "“"Red Roomy"' followed by Seaweed extract, Lysin and Vit.B12 on "“Bez-El-Anza"” the highest value during the $1^{\text {st }}$ season.

During the $2^{\text {nd }}$ season, Vit.B12 on "Bez-ElAnza" followed by Lysin and Tyrosin on "Red Roomy" cultivar recorded the least values. While during the $3^{\text {rd }}$ season, Vit.B12 on "BezEl-Anza" followed by Methionin and Tyrosin on "Red Roomy" exhibited the least values

\section{TSS / acid ratio:}

Table (4) showed that during the three seasons of study, all tested treatments significantly surpassed the control respecting TSS/acid ratio with no significant differences between them. The most effective treatment in this respect was Lysin during the $1^{\text {st }}$ season (52.62). Methionin and Tyrosin also recorded higher values in this respect.

Also, during the $2^{\text {nd }}$ season, the same table suggested that Methionin and Tyrosin demonstrated the highest values. Methionin and Vit.B12 recorded the highest values during the $3^{\text {rd }}$ season.

On the other side, significant differences could be observed between the studied cultivars during $1^{\text {st }}$ and $3^{\text {rd }}$ seasons. "Red Roomy" gave the highest value during the $1^{\text {st }}$ season, while "Thompson Seedless"' gave the highest values during the $2^{\text {nd }}$ and $3^{\text {rd }}$ seasons.

The interaction effect demonstrated that Methionin, Lysin and Tyrosin on "Red Roomy" followed by Seaweed extract, Methionin, Lysin and Vit.B12 on "Bez-El-Anza" cultivar recorded the highest values during the $1^{\text {st }}$ season.

During the $2^{\text {nd }}$ season, Lysin and Tyrosin on "Red Roomy" followed by Tyrosin on "Thompson Seedless" cultivar recorded the highest values. While during the $3^{\text {rd }}$ season, Vit.B12 on "Bez-El-Anza" followed by Methionin and Tyrosin on "Red Roomy" and then Vit.B6 and Vit.B12 on 'Thompson Seedless" cultivar exhibited the highest values.

\section{C/N ratio in one-year old wood:}

Table (5) showed during the three seasons of study, all tested treatments significantly surpassed the control respecting $\mathrm{C} / \mathrm{N}$ ratio with no significant differences between them. The most effective treatment in this respect was Vit.B12 at $150 \mathrm{ppm}$ (44.85). Seaweed extract also recorded a higher value in this respect. During the $2^{\text {nd }}$ season, the same table suggested that Seaweed extract, Methionin and Vit.B12 demonstrated the highest values. Seaweed extract, Lysin and Vit.B12 recorded the highest values during the $3^{\text {rd }}$ season.

On the other side, no significant differences could be observed between the studied cultivars during $1^{\text {st }}$ and $3^{\text {rd }}$ seasons. "Thompson Seedless" "gave the highest value during the $1^{\text {st }}$ and $3^{\text {rd }}$ season, while "Red Roomy"" gave the highest value during the $1^{\text {st }}$ season. The 
interaction effect demonstrated that Vit.B6 and Vit.B12 on "“Red Roomy"” during the $1^{\text {st }}$ season followed by Seaweed extract and Vit.B12 on "“Bez-El-Anza"” and "“Thompson Seedless" cultivars during the $2^{\text {nd }}$ and $3^{\text {rd }}$ seasons recorded the highest values.

\section{Discussion}

With regard to the chemical parameters of berries, algal extract raised TSS in juice and decreased acidity. In expansion, increment in TSS might be identified with enzymes which are available in algal extract that enhanced the synthesis of different proteins, acids and sugars. In expansion, increment in TSS might be identified with enzymes which are available in algal extract that enhanced the synthesis of different proteins, acids and sugars. TSS content in grapes of all grapevines treated with seaweed increased compared to control in the period to the end of harvest time. Grape ripening is not only determined by the rate of TSS accumulation, but also characterized by the rate of decline in organic acids. Table grapes freshly consuming require lower acidity than wine grapes and grapes to be consumed fresh should be chosen for balanced TSS and acid content.

The increase in leaf total chlorophyll content was reflected on increasing rate of photosynthesis rate and accumulation of carbohydrates reserves which lead to positive effect on fruit quality. In addition, Increase in TSS and TSS/acidity ratio may be related to enzymes which are present in seaweed extract that enhanced the synthesis of different proteins, acids and sugars. Khan et al. (2012); Mohamed and El-Sehrawy (2013) reported that increase in yield due to seaweed-treated vines, are thought to be associated with the hormonal substances present in the algae extracts. The essential of these materials on enhancing growth and vine nutritional status in favour of producing greater number of clusters/vine could explain the present results. Vitamin B1 (Thiamin) is a needful ingredient for biosynthesis of the coenzyme thiamin pyrophosphate. It plays an impotent role in carbohydrates metabolism .

\section{Conclusions}

Spraying algae extract, amino acids and vitamins with appropriate concentrations improved vine $\mathrm{C} / \mathrm{N}$ ratio, productivity and berry chemical attributes.

\section{Acknowledgment}

I would like to express my great and sincere appreciation to. Dr.Alhosein Hamada, Assoiciate Prof. of Agronomy, Fac. of Agric., Assiut Univ. for his kind help in data analysis.

\section{References}

Abada, M.A.M. (2014) 'A Comparative Study for the Effect of Green Tea Extract and Some Antioxidants on 'Thompson Seedless' Grapevines', International Journal of Plant and Soil Science, 3(10), pp. 1333-1342, doi: 10.9734/IJPSS/2014/8611

Abd El-aal, E.E.H.A. (2012) 'The synergistic effects of using some nutrients as well as antioxidant substances on growth, nutritional status and productivity of 'Thompson Seedless' grapevines grown under Sohag region', Ph.D. Thesis, Faculty of Agriculture, Sohag University, Egypt.

Abd-Elaal, A.H.M.,El-Masry, S.E.M.A., Abd El-Wahab, M.A. and Abd El-Latief, M.M.H. (2014) 'Relation of yield and berries quality of 'Thompson Seedless' grapevines to foliar application of some vitamins' ,World Rural Observations, 6 (2), pp.58 -64.

Abdelaal, A.M.K; Ahmed, F.F. and AbdElaal, E.E.H. (2013) 'The stimulative effects of using some nutrients and antioxidants on growth, nutritional status and yield of 'Thompson Seedless' grapes', Hort. Sci. J. of Suez CanalUniv., 1, pp 322-329.

Abdel-Aziz F.H., Uwakiem, M.Kh. and Ebrahiem M.M.M. (2017) 'Promoting 
berries colouration, yield and quality of Flame seedless grapevines by using amino acids enriched with different nutrients' , Assiut J. Agric. Sci., 98(13), pp 145-157.

Ahmed, F.F.,Abd El-Aal, A.H.M., El-Masry, S.E.M.A. and Farag, W.B.M.M. (2014) 'Response of Superior grapevines to foliar application of some micronutrients, calcium, amino acids and salicylic acid' ,World Rural Observations, 6 (3), pp. 5764.

Ahmed, F.F., Abd El-Aziz, F.H., Gobara A.A., El-Mamlouk, E.A.H. and Hashem, M.H.A. (2015) 'Behaviour of Superior grapevines to foliar application of some vitamins and amino acids',World Rural Observations, 7 (1), pp. 100-107.

Ahmed, F.F., Abdelaal, A.M. K. and Abd EIaal, E.E.H.A. (2012) 'Promoting productivity of 'Thompson Seedless' grapevines byapplication of some antioxidants and nutrients', Minia J. of Agric. Res. \& Develop., 32(3), pp. 527-542.

Ahmed, F.F., Ibrahiem, A.A.; Mansour, A.E.M.,Shaaban, E.A. and El-Shamaa, M.S. (2011) 'Response of 'Thompson Seedless' grapevines to application of some amino acids enriched with nutrients as well as organic and biofertilization', Res. J. Agric. Bio.Sci., 7 (2), pp. 282 -286.

Ahmed, M.A.M. (2016) 'Physiological studies on the effect of some silicon, boron and amino acid treatments on some olive cvs.' , Ph. D. Thesis. Fac. of Agric., of Al -Azhar Univ. (Assiut branch).

Al-Khawaga, A.S. (2014)'Impact of vitamins B and C, Glutamic acid and silicon on fruiting of Superior grapevines' , World Rural Observations, 6 (4), pp. 57-62.

Al-Wasfy, M.M.M. (2014)'The synergistic effects of using silicon with some vitamins on growth and fruiting of Flame seedless grapevines', Stem Cell, 5 (1), pp. 8 -13.

Carvalho R. P.; Pasqual, M. ; Silveira, H. R. O. ; Melo, P. C. ; Bispo, D. F. A.; Laredo, R. R. and Lima, L. A. S. (2019)' BNiágara Rosada table grapecultivated with seaweed extracts: physiological, nutritional and yielding behavior', J. Appli. Phyc. https://doi.org/10.1007/s10811-018-17247).

El-Sayed, M.E.A. (2013) 'Improving fruit quality and marketing of "Crimson Seedless" grape using some preharvest treatments' , J. Hort. Sci. and Ornamen. Plants, 5 (3), pp. 218-226.

El-Sharony T.F., El-Gioushy, S. F. and Amin, O. A. (2015) 'Effect of FoliarApplication with Algae and Plant Extracts on Growth, Yield and FruitQuality of Fruitful Mango Trees Cv. Fagri Kalan' , J. of Hort. 2, pp. 2 $-7$.

Gad El- Kareem, M.R. and Abd ElRahman, M.M.A. (2013) 'Response ofRuby seedless grapevines to foliar application of seaweed extract,salicylic acid and Roselle extract' , Hort. Sci. J. of Suez Canal Univ., (1), pp. 299- 303.

Khan, A.S., Bilal, A., Jaskani, M.J.,Rashid, A. and Malik, A.U. (2012) 'Foliar application of mixture of amino acids and seaweed extract improve growth and physicochemical properties of grapes', Int. J. Agric. Biol., 14 (3), pp. 383 - 388.

Madian, A.M. and Refaai, M.M. (2011) 'The synergistic effects of using B vitamins with the two amino acids tryptophan and methionene in 'Thompson Seedless' grapevines' , Minia J. Agric. Res. and Develop., 3 (3), pp. 445-455 .

Mohamed A. Y. and El- Sehrawy, O. A. M. (2013) 'Effect of seaweed extract on fruiting of Hindy Bisinnara mango trees',$J$. of American Science., 9 (6), pp. 537-544.

Mohamed A.R.M.A., Abdel-Aziz F.H., Mohamed M.A.Gobara A. (2013) 'Effect on foliar application of Sida Compound fertilizer on growth,yield, and fruit chemical composition of 'Early Superior' grapevine' Journal of Horticultural Research. 21(2), pp.53-57. doi:10.2478/johr-2013-0021

Mohamed, M. M. E. (2017) 'Promoting the yield quantitively and qualitatively of Flameseedless grapevines by using some amino acid enriched with different 
nutrients' , M.Sc. Thesis,Fac. of Agric., Minia Univ., Egypt.

Mohamed, T.M.M. (2014) 'Relation of fruiting in Superior grapevines with spraying salicylic acids and boron' $M$. Sc. Thesis Fac. of Agric., MiniaUniv., Egypt.

Mohamed, W.B.M.F. (2014) 'Effect of some amino acid, nutrient and salicylic acid treatments on Superior grapevine cv.' M. Sc. Thesis Fac. of Agric., Assiut Azhar Univ.Egypt.

SAS institute, (2008) 'The SAS system for windows' , release 9.2 Cary NC: SAS institute.

Steel, R.G. and Torrie, J. (1980) 'Principles and procedures of statistics', A biological approach. $2^{\text {nd }}$ Ed., Mc. Graw-Hill Book Co. Inc., New York, USA. 
Table 1. Effect of foliar application with some amino acids, vitamins and algae extract on Yield / Vine (kg) of "Bez-El-Anza", 'Thompson Seedless' and "Red Roomy" grape cultivars during 2017, 2018 and 2019 seasons.

\begin{tabular}{|c|c|c|c|c|c|c|c|c|c|c|c|c|}
\hline \multirow{2}{*}{ Cultivars(C) } & \multicolumn{3}{|c|}{ Bez-El-Anza } & \multicolumn{3}{|c|}{ Thompson Seedless } & \multicolumn{3}{|c|}{ Red Roomy } & \multicolumn{3}{|c|}{ Mean $(\mathrm{T})$} \\
\hline & 2017 & 2018 & 2019 & 2017 & 2018 & 2019 & 2017 & 2018 & 2019 & 2017 & 2018 & 2019 \\
\hline Seaweed $(2 \mathrm{~g} / \mathrm{L})$ & 3.06 & 2.74 & 2.03 & 6.85 & 7.21 & 7.35 & 11.60 & 12.90 & 11.41 & 7.17 & 7.62 & 6.93 \\
\hline Amino acid mix (500 ppm) & 3.56 & 2.92 & 2.92 & 7.63 & 7.80 & 6.98 & 14.58 & 15.02 & 12.46 & 8.59 & 8.58 & 7.45 \\
\hline Glycin (500 ppm) & 3.28 & 2.13 & 2.20 & 6.51 & 7.03 & 7.22 & 11.32 & 15.72 & 16.50 & 7.04 & 8.29 & 8.64 \\
\hline Mithionin (500 ppm) & 3.36 & 2.08 & 2.43 & 6.47 & 6.66 & 7.36 & 12.51 & 12.76 & 13.09 & 7.45 & 7.17 & 7.63 \\
\hline Lysin (500 ppm) & 3.75 & 2.12 & 1.82 & 6.76 & 8.29 & 7.36 & 13.69 & 14.64 & 14.24 & 8.07 & 8.35 & 7.81 \\
\hline Tyrosin (500 ppm) & 3.59 & 2.56 & 2.30 & 7.97 & 7.88 & 7.60 & 16.85 & 16.10 & 13.82 & 9.47 & 8.85 & 7.91 \\
\hline Folic acid (150 ppm) & 3.49 & 3.03 & 2.57 & 7.03 & 7.04 & 7.48 & 12.96 & 13.48 & 15.00 & 7.83 & 7.85 & 8.35 \\
\hline Vitamin B6 (150 ppm) & 2.88 & 2.13 & 2.40 & 6.94 & 7.05 & 7.07 & 11.66 & 12.24 & 13.74 & 7.16 & 7.14 & 7.74 \\
\hline Vitamin B12 (150 ppm) & 4.02 & 2.22 & 3.33 & 7.12 & 6.37 & 6.67 & 15.20 & 14.28 & 14.16 & 8.78 & 7.62 & 8.05 \\
\hline Control (water only) & 2.23 & 1.77 & 1.27 & 5.26 & 5.81 & 6.09 & 9.98 & 8.86 & 9.82 & 5.82 & 5.48 & 5.72 \\
\hline Mean (C) & 3.32 & 2.37 & 2.33 & 6.85 & 7.11 & 7.12 & 13.03 & 13.60 & 13.42 & 7.74 & 7.69 & 7.62 \\
\hline Season & \multicolumn{3}{|c|}{2017} & \multicolumn{4}{|c|}{2018} & \multicolumn{5}{|c|}{2019} \\
\hline $\mathrm{LSD}^{\prime}(\mathrm{T})$ & \multicolumn{3}{|c|}{0.55} & \multicolumn{4}{|c|}{0.60} & \multicolumn{5}{|c|}{0.65} \\
\hline $\mathrm{LSD}^{\prime}(\mathrm{C})$ & \multicolumn{3}{|c|}{0.13} & \multicolumn{3}{|r|}{0.34} & & \multicolumn{5}{|c|}{0.34} \\
\hline $\mathrm{LSD}^{\prime}(\mathrm{C} * \mathrm{~T})$ & \multicolumn{3}{|c|}{1.03} & \multicolumn{3}{|r|}{1.10} & & \multicolumn{5}{|c|}{1.20} \\
\hline
\end{tabular}


El-Sese et al., SVU-International Journal of Agricultural Sciences, 2 (1): 73-84, 2020

Table 2. Effect of foliar application with some amino acids, vitamins and algae extract on TSS (\%) of "Bez-El-Anza", "Thompson Seedless' and "Red Roomy” grape cultivars during 2017, 2018 and 2019 seasons.

\begin{tabular}{|c|c|c|c|c|c|c|c|c|c|c|c|c|}
\hline \multirow{2}{*}{ Cultivars(C) } & \multicolumn{3}{|c|}{ Bez-El-Anza } & \multicolumn{3}{|c|}{ Thompson Seedless } & \multicolumn{3}{|c|}{ Red Roomy } & \multicolumn{3}{|c|}{ Mean $(\mathrm{T})$} \\
\hline & 2017 & 2018 & 2019 & 2017 & 2018 & 2019 & 2017 & 2018 & 2019 & 2017 & 2018 & 2019 \\
\hline Seaweed $(2 \mathrm{~g} / \mathrm{L})$ & 17.16 & 15.08 & 15.20 & 22.88 & 21.80 & 21.12 & 17.96 & 17.48 & 18.12 & 19.33 & 18.12 & 18.15 \\
\hline Amino acid mix (500 ppm) & 16.80 & 16.44 & 15.72 & 23.00 & 20.48 & 21.84 & 17.08 & 17.32 & 18.04 & 18.96 & 18.08 & 18.53 \\
\hline Glycin (500 ppm) & 17.08 & 15.62 & 15.52 & 22.96 & 22.68 & 22.16 & 16.28 & 16.44 & 17.20 & 18.77 & 18.25 & 18.29 \\
\hline Mithionin (500 ppm) & 16.76 & 16.68 & 15.16 & 22.64 & 21.86 & 21.28 & 17.44 & 15.72 & 16.80 & 18.95 & 18.09 & 17.75 \\
\hline Lysin $(500 \mathrm{ppm})$ & 14.52 & 17.40 & 15.56 & 21.72 & 22.40 & 20.68 & 17.44 & 16.68 & 17.88 & 17.89 & 18.83 & 18.04 \\
\hline Tyrosin (500 ppm) & 15.40 & 14.48 & 16.36 & 23.16 & 22.32 & 21.60 & 17.68 & 17.40 & 15.24 & 18.75 & 18.07 & 17.73 \\
\hline Folic acid (150 ppm) & 14.76 & 15.00 & 15.30 & 22.08 & 20.76 & 22.32 & 16.84 & 15.48 & 16.60 & 17.89 & 17.08 & 18.07 \\
\hline Vitamin B6 (150 ppm) & 16.60 & 16.20 & 17.40 & 23.36 & 20.92 & 22.84 & 15.60 & 15.68 & 15.84 & 18.52 & 17.60 & 18.69 \\
\hline Vitamin B12 (150 ppm) & 14.80 & 14.24 & 13.88 & 21.40 & 21.36 & 22.16 & 17.96 & 16.20 & 15.68 & 18.05 & 17.27 & 17.24 \\
\hline Control (water only) & 12.72 & 13.96 & 13.00 & 20.96 & 19.96 & 20.40 & 16.24 & 15.24 & 15.16 & 16.64 & 16.39 & 16.19 \\
\hline Mean $(\mathrm{C})$ & 15.66 & 15.51 & 15.31 & 22.42 & 21.45 & 21.64 & 17.05 & 16.16 & 16.66 & 18.38 & 17.91 & 18.14 \\
\hline Season & \multicolumn{4}{|c|}{2017} & \multicolumn{4}{|c|}{2018} & \multicolumn{4}{|c|}{2019} \\
\hline $\mathrm{LSD}^{\prime}(\mathrm{T})$ & \multicolumn{4}{|c|}{0.80} & \multicolumn{4}{|c|}{0.69} & \multicolumn{4}{|c|}{0.66} \\
\hline $\mathrm{LSD}^{\prime}(\mathrm{C})$ & \multicolumn{4}{|c|}{0.22} & \multicolumn{4}{|c|}{0.48} & \multicolumn{4}{|c|}{0.42} \\
\hline $\mathrm{LSD}^{\prime}\left(\mathrm{C}^{*} \mathrm{~T}\right)$ & \multicolumn{4}{|c|}{1.64} & \multicolumn{4}{|c|}{1.29} & \multicolumn{4}{|c|}{1.24} \\
\hline
\end{tabular}


El-Sese et al., SVU-International Journal of Agricultural Sciences, 2 (1): 73-84, 2020

Table 3. Effect of foliar application with some amino acids, vitamins and algae extract on Total acidity (\%) of "Bez-El-Anza", 'Thompson Seedless' and "Red Roomy” grape cultivars during 2017, 2018 and 2019 seasons.

\begin{tabular}{|c|c|c|c|c|c|c|c|c|c|c|c|c|}
\hline \multirow{2}{*}{ Cultivars(C) } & \multicolumn{3}{|c|}{ Bez-El-Anza } & \multicolumn{3}{|c|}{ Thompson Seedless } & \multicolumn{3}{|c|}{ Red Roomy } & \multicolumn{3}{|c|}{ Mean $(\mathrm{T})$} \\
\hline & 2017 & 2018 & 2019 & 2017 & 2018 & 2019 & 2017 & 2018 & 2019 & 2017 & 2018 & 2019 \\
\hline Seaweed $(2 \mathrm{~g} / \mathrm{L})$ & 0.29 & 0.39 & 0.34 & 0.50 & 0.53 & 0.43 & 0.39 & 0.37 & 0.47 & 0.40 & 0.43 & 0.41 \\
\hline Amino acid mix (500 ppm) & 0.39 & 0.45 & 0.44 & 0.48 & 0.42 & 0.42 & 0.35 & 0.40 & 0.43 & 0.41 & 0.42 & 0.43 \\
\hline Glycin (500 ppm) & 0.42 & 0.45 & 0.47 & 0.54 & 0.55 & 0.45 & 0.35 & 0.48 & 0.37 & 0.44 & 0.50 & 0.43 \\
\hline Mithionin (500 ppm) & 0.30 & 0.34 & 0.35 & 0.54 & 0.46 & 0.46 & 0.27 & 0.30 & 0.28 & 0.37 & 0.37 & 0.36 \\
\hline Lysin (500 ppm) & 0.28 & 0.36 & 0.33 & 0.45 & 0.54 & 0.44 & 0.28 & 0.29 & 0.34 & 0.34 & 0.40 & 0.37 \\
\hline Tyrosin (500 ppm) & 0.38 & 0.48 & 0.43 & 0.46 & 0.40 & 0.42 & 0.28 & 0.23 & 0.28 & 0.37 & 0.37 & 0.38 \\
\hline Folic acid (150 ppm) & 0.35 & 0.68 & 0.40 & 0.48 & 0.46 & 0.46 & 0.35 & 0.31 & 0.32 & 0.39 & 0.48 & 0.39 \\
\hline Vitamin B6 (150 ppm) & 0.46 & 0.52 & 0.41 & 0.53 & 0.41 & 0.39 & 0.43 & 0.41 & 0.38 & 0.48 & 0.45 & 0.39 \\
\hline Vitamin B12 (150 ppm) & 0.28 & 0.27 & 0.23 & 0.49 & 0.51 & 0.41 & 0.41 & 0.47 & 0.42 & 0.39 & 0.42 & 0.35 \\
\hline Control (water only) & 0.54 & 0.50 & 0.59 & 0.58 & 0.49 & 0.49 & 0.46 & 0.55 & 0.52 & 0.53 & 0.51 & 0.53 \\
\hline Mean (C) & 0.37 & 0.44 & 0.40 & 0.51 & 0.48 & 0.44 & 0.36 & 0.38 & 0.38 & 0.41 & 0.43 & 0.41 \\
\hline Season & \multicolumn{4}{|c|}{2017} & \multicolumn{4}{|c|}{2018} & \multicolumn{4}{|c|}{2019} \\
\hline $\operatorname{LSD}^{\prime}(\mathrm{T})$ & \multicolumn{4}{|c|}{0.07} & \multicolumn{4}{|c|}{0.10} & \multicolumn{4}{|c|}{0.04} \\
\hline $\operatorname{LSD}^{\prime}(\mathrm{C})$ & \multicolumn{4}{|c|}{0.04} & \multicolumn{4}{|c|}{0.10} & \multicolumn{4}{|c|}{0.02} \\
\hline $\mathrm{LSD}^{\prime}(\mathrm{C} * \mathrm{~T})$ & \multicolumn{4}{|c|}{--} & \multicolumn{4}{|c|}{0.20} & \multicolumn{4}{|c|}{0.05} \\
\hline
\end{tabular}


Table 4. Effect of foliar application with some amino acids, vitamins and algae extract on TSS/Acid ratio of "Bez-El-Anza", 'Thompson Seedless' and "Red Roomy” grape cultivars during 2017, 2018 and 2019 seasons

\begin{tabular}{|c|c|c|c|c|c|c|c|c|c|c|c|c|}
\hline \multirow{2}{*}{ Cultivars(C) } & \multicolumn{3}{|c|}{ Bez-El-Anza } & \multicolumn{3}{|c|}{ Thompson Seedless } & \multicolumn{3}{|c|}{ Red Roomy } & \multicolumn{3}{|c|}{ Mean $(\mathrm{T})$} \\
\hline & 2017 & 2018 & 2019 & 2017 & 2018 & 2019 & 2017 & 2018 & 2019 & 2017 & 2018 & 2019 \\
\hline Seaweed $(2 \mathrm{~g} / \mathrm{L})$ & 58.29 & 38.67 & 44.71 & 45.35 & 41.13 & 49.17 & 45.57 & 47.65 & 38.31 & 48.33 & 42.14 & 44.27 \\
\hline Amino acid mix (500 ppm) & 42.88 & 36.53 & 35.73 & 48.08 & 48.76 & 52.41 & 48.55 & 43.3 & 41.95 & 46.24 & 43.05 & 43.09 \\
\hline Glycin (500 ppm) & 40.94 & 34.71 & 33.02 & 42.19 & 40.89 & 49.24 & 46.67 & 33.92 & 46.49 & 42.66 & 36.50 & 42.53 \\
\hline Mithionin (500 ppm) & 55.40 & 49.06 & 43.31 & 42.2 & 47.52 & 46.62 & 65.07 & 52.40 & 60.00 & 51.22 & 48.89 & 49.31 \\
\hline Lysin (500 ppm) & 52.42 & 48.33 & 47.15 & 48.15 & 41.30 & 47.00 & 62.85 & 57.52 & 52.59 & 52.62 & 47.08 & 48.76 \\
\hline Tyrosin (500 ppm) & 40.53 & 30.17 & 38.05 & 50.35 & 55.80 & 51.43 & 63.48 & 75.65 & 54.43 & 50.68 & 48.84 & 46.66 \\
\hline Folic acid (150 ppm) & 41.88 & 22.20 & 38.25 & 46.10 & 45.13 & 48.52 & 48.42 & 49.94 & 51.88 & 45.87 & 35.58 & 46.33 \\
\hline Vitamin B6 (150 ppm) & 35.8 & 31.39 & 42.44 & 44.08 & 51.02 & 58.44 & 35.93 & 37.84 & 41.68 & 38.58 & 39.11 & 47.92 \\
\hline Vitamin B12 (150 ppm) & 52.97 & 52.31 & 60.35 & 43.31 & 42.18 & 54.05 & 44.01 & 34.34 & 37.33 & 46.28 & 41.12 & 49.26 \\
\hline Control (water only) & 23.77 & 27.92 & 22.03 & 36.14 & 40.73 & 41.35 & 35.3 & 27.71 & 29.15 & 31.40 & 32.14 & 30.55 \\
\hline Mean (C) & 42.40 & 35.25 & 38.28 & 43.95 & 44.70 & 49.18 & 47.37 & 42.52 & 43.83 & 44.83 & 41.19 & 43.59 \\
\hline Season & \multicolumn{4}{|c|}{2017} & \multicolumn{4}{|c|}{2018} & \multicolumn{4}{|c|}{2019} \\
\hline $\mathrm{LSD}^{\prime}(\mathrm{T})$ & \multicolumn{4}{|c|}{7.96} & \multicolumn{4}{|c|}{8.19} & \multicolumn{4}{|c|}{2.19} \\
\hline $\mathrm{LSD}^{\prime}(\mathrm{C})$ & \multicolumn{3}{|c|}{5.47} & & \multicolumn{4}{|c|}{--} & \multicolumn{4}{|c|}{4.75} \\
\hline LSD' (C*T) & \multicolumn{3}{|c|}{19.75} & & \multicolumn{4}{|c|}{15.74} & \multicolumn{4}{|c|}{5.85} \\
\hline
\end{tabular}


El-Sese et al., SVU-International Journal of Agricultural Sciences, 2 (1): 73-84, 2020

Table 5. Effect of foliar application with some amino acids, vitamins and algae extract on C/N Ratio ratio of "Bez-El-Anza",

'Thompson Seedless' and "Red Roomy” grape cultivars during 2018, 2019 and 2020 seasons.

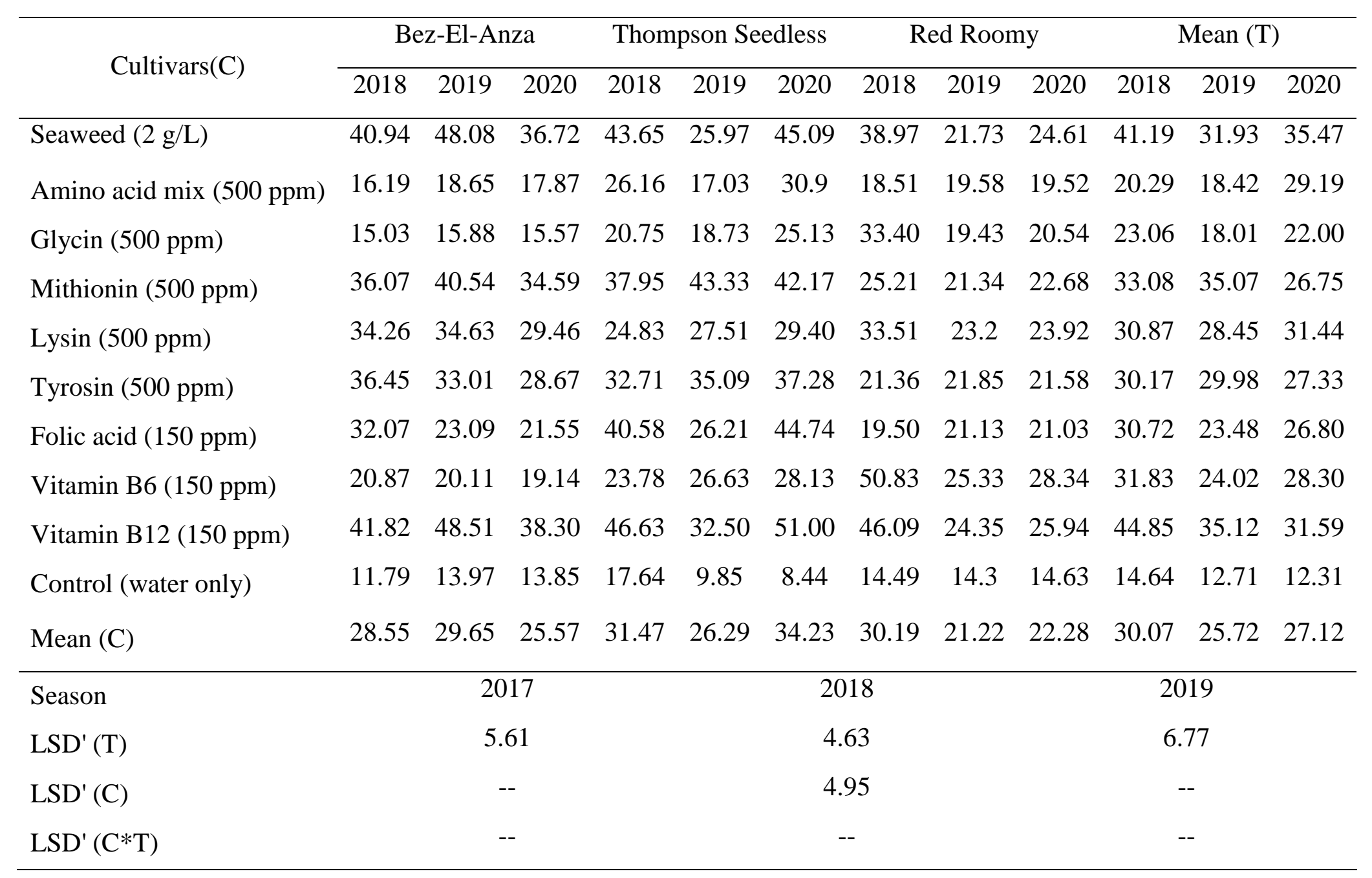

